\title{
Major Reduction in Chemical Curatives for Rubber Articles
}

\author{
Ali Ansarifar* and Saad H Sheikh \\ Department of Materials, Loughborough University, UK
}

Submission: April 15, 2019; Published: May 07, 2019

*Corresponding author: Ali Ansarifar, Department of Materials, Loughborough University, Leicestershire LE11 3TU UK.

\section{Opinion}

The sulfur cure system in the ethylene-propylene-diene (EPDM)-based Curtain Wall Seal (CWS) has two accelerators, adding up to 2.75 parts per hundred rubber (phr) by weight, and two activators (ZnO: 5phr, stearic acid:1phr) [1]. In total, 8.75phr chemicals are used to fully cure the article with $1 \mathrm{phr}$ elemental sulfur. In rubber formulations, chemical curatives are indispensable and once reacted with sulfur at elevated temperature, they produce crosslinks between the rubber chains and provide shape stability, which is essential for the performance, durability and life of the final product in service. Excessive use of chemical curatives is harmful to health, safety, and the environment. According to the European Directive 67/548/EEC, chemicals such as sulfenamide accelerators, zinc oxide and stearic acid are very toxic to aquatic organisms [2]. Stearic acid causes skin and eye irritation in human and is classified as highly flammable [3]. These chemicals are used extensively in the sulfur vulcanization of a wide range of EPDMbased rubber articles.
Keywords: Ethylene-Propylene-Diene rubber; N-tert-butyl-2-benzothiazole sulfenamide; Zinc oxide; Stearic Acid; Vulcanization; Oscillating Disc Rheometer

\section{Aims \& Objectives}

The aim of this study was to significantly reduce use of $\mathrm{N}$-tert-butyl-2-benzothiazole sulfenamide (a fast curing delayed action accelerator, Santocure TBBS) and zinc oxide (primary activator) in the sulfur cure systems of EPDM-based Curtain Wall Seal and eliminate stearic acid (secondary activator) entirely from the cure system. A new method for measuring the exact optimum amount of the chemical curatives required in the sulfur vulcanization of EPDM rubber was used [4]. All the cure tests were performed at $160^{\circ} \mathrm{C}$ in an oscillating disc rheometer (ODR) curemeter to produce cure traces from which scorch and optimum cure times, cure rate index and minimum and maximum torques were measured.

Results

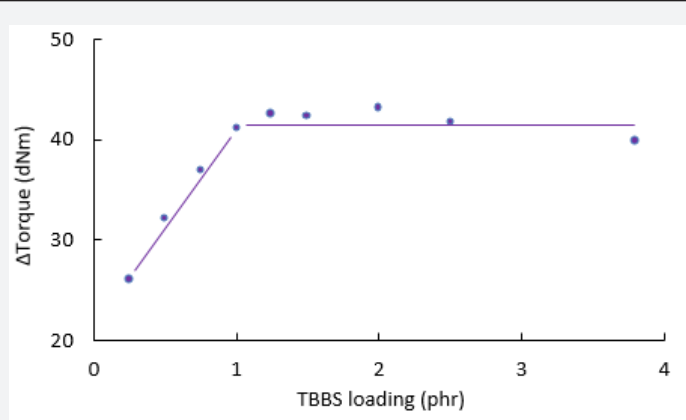

Figure 1: $\triangle$ Torque versus TBBS loading for the rubber with $1 \mathrm{phr}$ sulfur.

Figure 1 demonstrates $\Delta$ torque versus TBBS loading for the EPDM rubber with $1 \mathrm{phr}$ sulfur. $\triangle$ Torque, which is the difference between the maximum and minimum torques on the cure trace of the rubber and is an indirect indication of crosslink density changes in the rubber, increased steeply from 26 to $42 \mathrm{dNm}$ as the loading of TBBS was boosted from 0.25 to $1 \mathrm{phr}$. Subsequently, there was no improvement in $\Delta$ torque once the amount of TBBS reached 3.8phr. Apparently, 1phr TBBS was enough to react the sulfur with the rubber. Zinc oxide was then added to improve the efficiency of TBBS. $\Delta$ Torque rose noticeably from $41 \mathrm{dNm}$ at $0 \mathrm{phr} \mathrm{ZnO}$ to $56 \mathrm{dNm}$ at $0.075 \mathrm{phr} \mathrm{ZnO}$ and the rate of increase slowed down significantly thereafter. $\Delta$ torque then reached to about $67 \mathrm{dNm}$ when the loading of $\mathrm{ZnO}$ was raised by an additional $0.325 \mathrm{phr}$ (Figure 2). It is interesting that a small amount of $\mathrm{ZnO}$, 
i.e. as low as $0.075 \mathrm{phr}$, had such a major influence on the performance of TBBS in the cure system as indicated by a significant rise in $\Delta$ torque. When $0.5 \mathrm{phr}$ stearic acid was mixed with the EPDM rubber with $1 \mathrm{phr}$ sulfur, $1 \mathrm{phr}$ TBBS \& $0.075 \mathrm{phr} \mathrm{ZnO}$, storque decreased from 56 to $47 \mathrm{dNm}$. $\Delta$ torque subsequently continued decreasing slowly to about $42 \mathrm{dNm}$ when the loading of stearic acid was raised to 2.5phr (Figure 3). Evidently, the crosslink density as indicated by $\Delta$ torque did not benefit from the addition of stearic acid to the rubber. Moreover, the scorch and optimum cure times increased, and the rate of cure as indicated by the cure rate index declined noticeably when stearic added was added [4]. Consequently, stearic acid was eliminated from the cure system entirely. In the absence of stearic acid, no zinc stearate was formed in the rubber. Hence, zinc stearate is not an essential ingredient in the curing of rubber as has been claimed [5]. The scorch time $\left(\mathrm{t}_{\mathrm{s} 2}\right)$ and the optimum cure time $\left(t_{95}\right)$ were $6.2 \& 21.5 \mathrm{~min}$, respectively. The rate of cure as indicated by the cure rate index (CRI) was $6.5 \mathrm{~min}^{-1}$. Clearly, requirement for the accelerator and primary and secondary activators to fully cure the rubber at $1 \mathrm{phr}$ loading of sulfur is much lower, i.e. TBBS by $64 \mathrm{wt} \%$, zinc oxide by $98.5 \mathrm{wt} \%$ and stearic acid by $100 \mathrm{wt} \%$, than the amounts currently used in the cure system of the CWS at the same loading of sulfur. All the indications are that a significant decrease in the loading of the chemical curatives in the cure system has no adverse effect on the vulcanization of the article. In fact, cure efficiency improves when less accelerators and activators are used with sulfur. This method can be applied to reduce excessive amount of the chemical curatives in other industrial rubber articles.

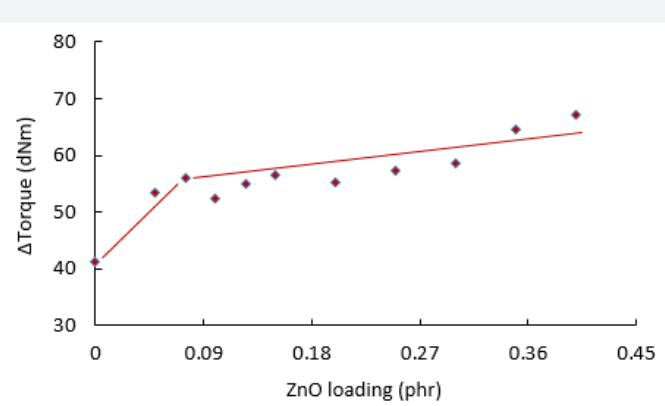

Figure 2: $\Delta$ Torque versus $\mathrm{ZnO}$ loading for the rubber with $1 \mathrm{phr}$ sulfur \& $1 \mathrm{phr}$ TBBS.

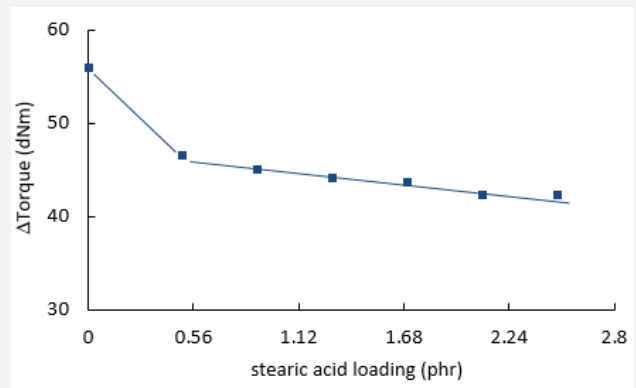

Figure 3: $\triangle$ Torque versus stearic acid loading for the rubber with $1 \mathrm{phr}$ sulfur \& $1 \mathrm{phr}$ TBBS \& $0.075 \mathrm{phr} \mathrm{ZnO}$.

\section{References}

1. Ciullo PA, Hewitt N (1999) The rubber formulary. Noyes Publications, pp. 281.

2. Regulation (EC) No 1272/2008(2009) Regulation (EC) No 1272/2008 on classification, labelling and packaging of substances and mixtures.

3. European Directive 98/24/EC, Risks related to chemical agents at work (1998) Directive 98/24/EC - risks related to chemical agents at work.
4. Saad Sheikh H, Xuena Yin, Ali Ansarifar, Keith Yendall (2017) The potential of kaolin as a reinforcing filler for rubber composites with new sulfur cure systems, Journal of Reinforced Plastics and Composites 36(16): 1132-1145.

5. Datta RN, Flexsys BV (2002) Rubber curing systems. Rapra Rev Rep 12: 1-37. 
(C) This work is licensed under Creative BY DOI: 10.19080/AJOP.2019.02.555594
Your next submission with Juniper Publishers

will reach you the below assets

- Quality Editorial service

- Swift Peer Review

- Reprints availability

- E-prints Service

- Manuscript Podcast for convenient understanding

- Global attainment for your research

- Manuscript accessibility in different formats

( Pdf, E-pub, Full Text, Audio)

- Unceasing customer service

Track the below URL for one-step submission https://juniperpublishers.com/online-submission.php 